УДК 327(510)"1959/1962"

NIU Jun, Ph. D.

\title{
“TURN TO THE LEFT" IN CHINESE FOREIGN POLICY FROM THE LATE 1950S TO 1962
}

\begin{abstract}
This article explores the radicalization process of China's foreign policy from the late 1950s to 1962 . It argues that the initiative for foreign policy radicalization was very much founded in domestic politics, particularly since the key role was exercised by the overt struggle inside the CPC leadership over the results of the Great Leap Forward.
\end{abstract}

Key words: China's diplomacy, radicalization, border conflict

As the study of the Chinese foreign policy deepens, questions such as the change of Chinese foreign policy from 1959 to 1962 and its impact on the later foreign policy of China have become focal points for the Chinese academic community. Emphasizing the unprecedented severe domestic and international milieus facing China on the juncture of 1962, recent studies in China point out the co-existence of the unceasing incidents surrounding China and the changing domestic political situation, and try to analyze these phenomena against the backdrop of change in Chinese foreign policy, asserting that these phenomena, indeed, had huge impact on the diplomacy of China. ${ }^{1}$ One question should be raised and answered explicitly: whether these two phenomena were correlated and whether they influenced each other? Further on, in terms of influencing Chinese foreign policy, which factor was of more determining effect? It seems to be insufficient to merely enumerate the phenomena and describe these processes. In the light of the queries existing in the previous studies, this article aims at discussing the features of the interactions between the continuously changing international milieu and the domestic politics in China during the period, while singling out the impetus of change in Chinese foreign policy, as well as pointing out the historical niche of this change in the development of Chinese foreign policy during the 1960 s.

1 Zhang Baijia, “Biandong zhong de guoji huanjing yu zhongguo duimei zhengce”, pp. 190-91; and Li Jie, "60 niandai zhongguo guonei jushi de bianhua yu zhongmei guanxi”, pp. 264-70, both in Jiang Changbin and Robert S. Ross eds. 1955-1971 nian de zhongme guanxi - huanhe zhiqian: lengzhan chongtu yu kezhi de zai tantao, Beijing: Shijie zhishi, 1998. 


\section{Turmoil of the $1950 \mathrm{~s}$}

This article argues that the Chinese foreign policy underwent changes in the year of 1962, as it was the turning point towards the "left". First of all, we need to clarify what were the basic features of the so-called leftist Chinese foreign policy, for the conceptions of "left" and "extreme left" had different definitions under various political circumstances. During the Cold War era, in Chinese politics, "left", to put it simply, meant to pursue goals which were beyond the time or higher than the ones that were realistically possible. When extended to the domain of Chinese foreign policy, the so-called "left" or "extreme left" foreign policy included the following four basic characteristics:

First, in theoretical dimension, it held a dogmatic position toward Lenin's doctrine of "time", while simply asserting that the world is "in a time when capitalism and imperialism are moving toward destruction, and socialism and communism are striding toward victory," and therefore does not acknowledge the possibility of maintaining peace for a long period of time. ${ }^{2}$

Second, it exaggerated China's position and influence in world politics, manifested in "China as a revolution center" theory, such as proclaiming China as "the focus of the world contradictions and the center of the world revolutionary storm," and so on. "China as a revolution center" theory reflected Chinese leaders' strategic thinking on the important issues such as China's position and influence in world politics. From a deeper perspective, it was more or less involved with the "Chinese Centralism" view in the history of China.

Third, it put so-called proletarian internationalism in a supreme position, therefore denying the paramount status of national interests in making and implementing foreign policies, declaring the "proletarian internationalism" to be "the highest guiding principle" of Chinese foreign policy. ${ }^{4}$

Fourth, in terms of specific policy domains, it adopted strategies such as "to strike enemies with two fists" (liang ge quan tou da ren), and "to make attacks in all directions" (si mian chu ji).

The second thesis, very much related to the first one, supposes that the Chinese foreign policy was undergoing a fundamental change in the early 1960s. Since the proposing of the "Five Peaceful Co-existence Principles" in 1954, the Chinese foreign policy had ushered in a process of smooth development more than before. However, this momentum had not lasted for too long before it was interrupted by the unfolding of two events, which were going to ultimately re-mold the direction of Chinese foreign policy. These two events were the deterioration of the Sino-Soviet alliance and the unleashing of the "Great Leap Forward" movement.

Since the late 1950s, the Sino-Soviet alliance had experienced an allround decline. One of the key issues was the relationship between the one who

2 Lin Biao, "Renmin zhanzheng shengli wansui", People's Daily, September 3, 1965; Lin Biao, "Zai shoudu renmin jinian shiyue geming wushi zhounian dahui shang de jianghua", November 7 , 1967; Lin Biao, “Zou shehui zhuyi daolu, haishi zou ziben zhuyi daolu?”, August 15, 1967.

3 Lin Biao, "Renmin zhanzheng shengli wansui”; "Zhongguo gongchandang zhongyang weiyuanhui tongzhi”, People's Daily, May 17, 1966.

$4 \quad$ "Zhongguo gongchandang bajie zhongyang weiyuanhui di shiyi ci quanti huiyi gongbao", People's Daily, August 14, 1966. 
led (the Soviet) and the one who was being-led (China), which took shape during the formation of the Sino-Soviet alliance. This kind of situation could no longer continue due to the jolt of Poland and Hungary incidents in 1956. The change in such a relationship manifested itself through the following two aspects:

First, capitalizing on the severe crisis the Soviet Union was facing due to the incidents in Poland and Hungary, the Chinese leadership compelled the Soviet leaders to change their way in dealing with the inter-state relations within the Socialist bloc by releasing the Manifesto Concerning Developing and Further Strengthening the Basis of Friendship and Cooperation between the Soviet Union and Other Socialist Countries, in which the Soviet Union was forced to acknowledge previous mistakes when dealing with other socialist countries. ${ }^{5}$ Second, China's role had risen up within the Socialist bloc, and in particular, China's influence had been ostensibly strengthened, which was demonstrated by the Chinese leaders' activities during the Moscow Conference in November 1957.

Chinese leadership might have believed that there was no longer a relationship of leading and being-led between China and the Soviet Union. ${ }^{6}$ Previous Soviet relationship with other countries inside the Socialist camp, especially in its relationship with China, often characterized as the "cat-mouse relationship" and "father-son relationship", had been fundamentally changed.' Therefore, Chinese leaders could no longer withstand the arrogant attitude of the Soviet Union and they rebuked it as the repeating of mistakes of the Stalin period. For example, Mao complained the "now again (you are) doing what Stalin has done" when the Soviet side raised the suggestion to establish the "joint fleet" and "long-wave radio station" in spring 1958, Mao complained that "now [you are] doing what Stalin did". ${ }^{8}$

The Sino-Soviet alliance was a giant and crucial cornerstone of Chinese foreign relations at the time. Once such a cornerstone was shaken, there would be an overall instability in Chinese foreign relations, and even in Chinese domestic politics, which would be demonstrated by later history. Chinese leaders might not have expected the extent to which the deterioration of the Sino-Soviet alliance would have impact on China.

Soon after the deterioration of the Sino-Soviet alliance, there emerged a tendency of fundamental change in the Chinese domestic policy. Two important events happened in China from the spring of 1957 to 1959. One was the so-called "mizhu zhengfeng" (the Democratic Rectification) in the spring of 1957, aim of which was to resolve the contradictions between the masses and some party cadres through "democratic rectification". Another was the Great Leap Forward

5 Pei Jianzhang, ed., Zhonghua renmin gongheguo waijiao shi, 1949-1956, Vol. 2, Beijing: shijie zhishi chubanshe, 1994, pp. 37-38, 61-62; Zhou Enlai nianpu, 1949-1976, Vol. 2, 1997, pp. 63031; Mao Zedong, "Xi qu lishi jiaoxun, fandui daguo shaowen zhuyi", September 18, 1956, Mao Zedong waijiao wenxuan, Beijing: Zhongyang wenxian, 1994, pp. 251-262.

6 Yang Kuisong and Chen Jian, "Mao Zedong yu zhongsu tongmeng de xingshuai”, pp. 359-360; Li Jie, “Cong jiemeng dao polie: zhongsu lunzhan de qiyin”, p. 442, in Li Danhui ed., Beijing yu Mosike: cong lianmeng zouxiang duikang, Guangxi: Guangxi shifan daxue chubanshe, 2002.

7 On the terms of "Father-Son Party Relationship" and "Cat-Mouse Party Relationship", see Mao Zedong, "Tong sulian zhuhua dashi youjin de tanhua”, July 22, 1958, Mao Zedong waijiao wenxuan, p. 324.

8 Mao Zedong, “Tong sulian zhuhua dashi youjin de tanhua”, July 22, 1958, p. 331. 
launched in 1958, with an aim of accelerating the steps of modernization of Chinese economy and trying to outpace the Western powers such as Britain and the U.S. and achieve communism in China in the shortest possible period.

Both the Democratic Rectification and the Great Leap Forward ended as a great debacle. The former directly caused the anti-rightists struggle, intensifying the social contradictions, whereas the latter led to three years of catastrophic economic recession, and significantly aggravated the tense atmosphere within the Chinese Communist Party. Particularly, by the summer of 1959 it had become evident that the Great Leap Forward could not be carried on any more. Opinions to correct the mistakes of the Great Leap Forward were voiced within the Chinese leadership. Mao Zedong, however, refuted all critical opinions within the party as "rightist", and regarded the emergence of different opinions as "the continuance of the life and death struggle between the two antagonistic classes". ${ }^{9}$ Marshall Peng Dehuai, who fought shoulder to shoulder with Mao for more than twenty years, was brought down completely.

It is worth noting that almost at the same time Sino-Soviet relations were also slipping into crises. Believing that Khrushchev's talk about the communes in Poland in July 1959 was an insinuation about the People's Communes Movement, Mao Zedong virtually made up his mind to publicly split with the Soviet Union. Khrushchev's talk, which was published in Neibu cankao (Internal References) for the CCP leadership and was regarded as a hint at attacking the people's communes, in the eyes of Mao, echoed Peng Dehuai's criticism at home and was aimed at hitting at him personally while he was already down. In autumn 1959, no later than spring of 1960, Mao promptly ordered to strike the "opposition and suspicion factions" close to the Soviet Union, while he was even considering to publish Khrushchev's "anti-communes" speech in the People's Daily, ${ }^{10}$ which was ultimately not put into circulation when other leaders disagreed with this idea. ${ }^{11}$

Khrushchev probably did not quite understand Mao's wrath. After his visit to the United States, Khrushchev came to Beijing in hope of persuading Mao to go along with Soviet foreign policy. At the National Day reception on September 30, Khrushchev could not help hinting to Chinese leaders that they needed to revise their foreign policy. ${ }^{12}$ During the meeting with Chinese leaders, Khrushchev criticized that China had adopted a policy of "adventurism" regarding the Taiwan Strait in summer 1958 and the Sino-Indian border conflict in summer 1959. ${ }^{13} \mathrm{Mao}$, repugnant by Khrushchev's criticism, condemned him as a "rightist opportunist," and claimed that the Soviet Union "is afraid of two things: one is imperialism,

9 Mao Zedong. "How to Treat the Revolutionary Masses Movements", August 15, 1959; "The Origins of Machinegun and Trench Mortar and Others", August 16, 1959, in Jianguo yilai Mao Zedong wengao, Vol. 8, pp. 447, 451.

10 Mao Zedong, "Guanyu yanjiu renmingongshe wenti de piyu”, July 29, August 1, 1959, in Jianguo yilai Mao Zedong wengao, Vol. 8, pp. 390-92. Mao Zedong, "Guanyu dui renmingonshe jinxing diaocha yanjiu wenti gei Wu Lengxi, Chen Boda, Hu Qiaomu de xin", August 9, 1959; "Guanyu zhuyi fabiao guowai duihua pinglun wenti de piyu", May 4, 1959, ibid., pp. 462-463, 504.

11 Wu Lengxi, Shinian lunzhan, Vol. 1, Beijing: Zhongyang wenxian chubanshe, 1999, p. 204.

12 Alan J. Day, ed., China and the Soviet Union, 1949-1984, London: The East Press, 1985, pp. 14-15.

13 “Qiansulian guojia xin pilu de youguan 1959-1962 nian zhongyin guanxi wenxian”, Dangshi yanjiu ziliao, Vol. 8, 1998, pp. 19-20; Li Yueran, Waijiao wutai shang de xinzhongguo linxiu, Beijing: Waiyu Jiaoxue, 1994, pp. 160-64. 
and another is communism in China." ${ }^{14}$ In fact, this Sino-Soviet summit became a turning point in the Sino-Soviet alliance towards eventual rift.

As the Great Leap Forward was unfolding, situation in the Chinese neighborhood began to deteriorate since the summer of 1959. Chinese border conflict with India intensified, two sides went into military conflict along the Longjiu and Gongkashan passes in August, thus creating an explosive situation along the Sino-Indian border. In a way, the Sino-Indian border conflict was a harbinger of the process of deterioration in China's relations with its neighbors. In the summer of 1960, the Sino-Soviet border also became restless. Meanwhile, the situation in Indochina became tense due to the turmoil in Laos, especially after America evidently strengthened her direct intervention into the region.

Seriously concerned with this situation, Chinese leaders believed that "now the international anti-China tide is on the rise", while Mao said that the forces of "imperialism", "revisionism", and "reactionaries" were all involved. ${ }^{15}$

\section{Revision of course since the early 1960 s}

Starting from November 1959 to the first half of 1960, Chinese leadership spent quite a lot time on discussing "international issues" in order to decide how to comprehend and respond to the deteriorating strategic environment. ${ }^{16}$

It did not take that long, however, for the Chinese leaders to decide to adopt firm principles of response. At the Standing Committee Meeting of the CCP Politburo presided by Mao Zedong during January 7-17 1960, Chinese leadership concluded that "new initiatives should be adopted vigorously in order to create a new situation in foreign policy."17 Soon afterwards, the CCP Politburo also convened several more times and it discussed specific ways of policy implementation. Pragmatism re-emerged in Chinese diplomacy soon after that.

First of all, in terms of Sino-Soviet relations, Chinese leaders were not only determined to avoid the split, but also to strive to "reach a unity based on new foundations." ${ }^{18}$ This is why the Chinese, after several months of disputes with the Soviet Union, even after the poignant clash at the Bucharest Conference and the withdrawal of all Soviet experts from China, still reached an understanding with the Soviet leaders at the Moscow Conference of 81 Communist Parties and Workers' Parties in December 1960, that is, "to confer together on anything that

14 Mao Zedong, "Guanyu guoji xingshi de jianghua tigang”, in Dangshi yanjiu ziliao, Vol. 8, 1998, pp. 19-20; Yu Zhan, "Yici bufunchang de shiming", in Xinzhongguo waijiao fengyun, Beijing: Shijie zhishi, 1994, p. 18.

15 Wu Lengxi, Shinian lunzhan, Vol. 1, p. 234.

16 The situation concerning these discussions still cannot be verified by the archives. However, some important publications have disclosed that many discussions of this kind had been carried out. For instance, we can find this in both Zhou Enlai nianpu (The Chronology of Zhou Enlai) Vol. 2 and Wu Lengxi, Shinian lunzhan (A Decade of Polemics) Vol. 1, which thus provide important hints.

17 Wu Lengxi, Shinian lunzhan, Vol. 1, p. 248.

18 Ibid., p. 241. 
may come up so as to avoid conflict." ${ }^{19}$ The bilateral relations were improved after a follow-up state visit to the Soviet Union by the Chinese Chairman Liu Shaoqi.

When deciding to "create a new situation in foreign policy," Chinese leaders also had to find ways to resolve the Sino-Indian border conflict. At the meeting of the Standing Committee of the Politburo in January 1960, Chinese leadership outlined the guidelines regarding the peaceful resolution of the SinoIndian border disputes and it proposed to reach a compromise with India through "mutual understanding and mutual concession" (huliang hurang), that is, "we are to make some concessions, as long as India does too." It was decided at the same meeting that Zhou Enlai should visit New Delhi to negotiate with the Indians in person. ${ }^{20}$ Meanwhile, Chinese troops stationed along the Sino-Indian border received an order to adopt measures in order to avoid opening fire, patrolling, putting down rebellions, hunting, conducting military exercise, and making explosions within the area of twenty kilometers from the line of actual control, so as to avoid possible military clashes with Indians. ${ }^{21}$

After the meeting, Zhou Enlai started preparing for the visit to India, and he worked out The Proposal Concerning the Border Issue Meeting between the Premiers of China and India (Draft) that suggested to defuse tensions, but also not to be afraid of a delayed resolution, while setting the goal of this visit to be one of "further relaxation" of the bilateral relations and "preparing conditions" for a peaceful resolution of the border issues in the future. ${ }^{22}$ After Zhou's visit to India in April, the situation along the Sino-Indian border cooled down.

Chinese leaders had a thorough discussion of the border issues with all neighboring countries at a January meeting, when they set up basic guidelines to resolve border issues through negotiations step by step and as quickly as possible. The rough order was to try to resolve the Sino-Indian border issue first, while trying to resolve the border issues with North Korea and Mongolia as quickly as possible, and to accelerate the pace of resolving the border issues with Burma, Nepal, and Laos. It was concluded that the border issues with Vietnam, because of its ongoing war against America could be temporarily put aside. China had the longest borderline with the Soviet Union and the problems were also very complicated, but still China should try to resolve them. ${ }^{23}$ Factually, as Zhou Enlai was preparing for his visit to India, China also started resolving her border issues with other neighboring countries.

China's policy toward Indochina was also facing the pressure of adjustment, as the tensions went up. Two problems were on the table. One was whether to support the military struggle by the Vietnam Worker's Party (the VWP) in South Vietnam, and another was how to solve the Laos crisis. Comparatively speaking, at the time Chinese leaders were more occupied by the Laos crisis. China's persistent stance and efforts on the peaceful resolution of the Laos crisis during this period may better reflect the main characteristics of China's Indochina policy. During this

19 "Huigu yu sikao - yu zhongsu guanxi qinlizhe de duihua", in Li Danhui, Beijing yu mosike: cong lianmeng zouxiang duikang, p. 474.

20 Ibid., p. 248.

21 Lei Yingfu and Chen Xianyi. Tongshuaibu canmou de zhuihuai, Nanjing: Jiangsu wenyi chubanshe, 1994, p. 219.

22 Zhou Enlai nianpu, Vol. 2, p. 302.

23 Wu Lengxi, Shinian lunzhan, Vol. 1, p. 248. 
period, China was active in bringing together the Geneva Conference to resolve the Laos crisis and Beijing played an important role in the final signing of the Neutral Statement Concerning Laos and its related agreements. ${ }^{24}$

Under pressure of the dramatic changes in the situation in South Vietnam in 1959 and 1960, the VWP's leaders began to change their strategic guideline for strengthening the construction in the North and striving for peaceful unification. ${ }^{25}$ A policy of strengthening the military struggle in the South was established at the Third National Congress of the VWP in September $1960 .{ }^{26}$ This policy change of the VWP confronted China with a very complex situation. China clearly declared before that the VWP should put forward as its prime task the consolidation and construction of the North, while adopting in the South "a guideline of long-term lurk, accumulation of strength, contacting the masses, and waiting for the opportunity."27 Now, however, China had to make a choice between the contradictory policy goals of maintaining peace in Indochina and preventing large-scale American military intervention on one hand and supporting its traditional ally on the other.

China promptly expressed her support of the VWP's effort to strengthen the armed struggle in the South. ${ }^{28}$ On the other hand, however, China did not want the leaders of the VWP to completely rule out the option of a political resolution, precisely it did not want the scale of war in South Vietnam to become too large to bring about a large-scale American military intervention. Beijing stressed again and again that Hanoi should adopt a "flexible strategy", and "combine political struggle with military struggle." ${ }^{29}$ Up until mid-1961, China still publicly declared that it supported Vietnam's struggle to "strive for the peaceful unification of the motherland" according to the Geneva agreements. ${ }^{30}$

Even when the United States was observed as prone to escalating intervention in Indochina, Chinese leaders still made an effort to break the stalemate in Sino-American relations. Although such an effort was a very limited probe, it could, in a sense, demonstrate Chinese leaders' determination in adjusting Chinese foreign policy.

At the standing committee meeting of the CCP Politburo in January 1960, Chinese leaders also outlined a guideline for handling Chinese relations with the United States: "To talk but not in haste, to talk but not to break." That is to continue to negotiate with the Americans and not to break off the talks and also not to establish diplomatic relations with the U.S. in haste. ${ }^{31}$ Mao Zedong himself showed interest in

24 Jiejue laowo wenti de kuoda de rineiwa huiyi wenjian huibian, Beijing: shijie zhishi chubanshe, 1962, pp. 2-11.

25 Shi Yinhong, Meiguo zai yuenan de ganshe he zhanzheng, 1993, pp. 66-75.

26 On the changes in the VWP policy, see Shi Hongyin, ibid.

27 Guo Ming, ed., Zhongyue guanxi yanbian shinia, Guangxi renmin chubanshe, 1992, pp. 66-67.

28 "Yuenan gemin he jianshe de xin lichengbei", People's Daily, September 12, 1960.

29 Yang Kuisong, Mao Zedong yu yinduzhina zhanzheng; Li Danhui, ed., Zhongguo yu yingduzhina zhanzheng, Hongkong: tiandi tushu chubanshe, 2000, p. 36; Guo Ming, Zhongyue guanxi yanbian sishi nian, p. 67.

30 "Zhou Enlai zhongli zai huanying yuenan Fang Wentong zongli de guoyan shang de jianghua", June 12, 1961, in Zhonghua renmin gongheguo duiwai guanxi wenjianji, Vol. 8, Beijing: shijie zhishi chuban she, 1962, p. 181. 
a report of January 1960 which analyzed the possible change in the U.S. China policy. The report concluded that the U.S., based on certain reasons, might increase contacts with China in the future, and try to use the Warsaw talks to make further probes. ${ }^{32}$ Of course, this policy also had something to do with the on-going presidential election in the U.S., which opened a window for the Chinese leaders to understand the American policy towards China.

Zhou Enlai, when meeting British Marshall Montgomery in May 1960, indicated that China was willing to resolve the Taiwan issue peacefully, as long as the U.S. announced that it was willing to withdraw American troops from Taiwan. China and the U.S. could then start negotiations. ${ }^{33}$ When meeting American journalist Edgar Snow on August 30, Zhou proposed a more flexible suggestion that the U.S. had to first promise to withdraw its troops, but the problems of when and how to do it could be left for future discussion. ${ }^{34}$ On October 18, Zhou Enlai again met Snow, expounding on Chinese stances and policies of disarmament, Chinese representation in the U.N., nuclear tests, and the Taiwan issue, and introducing the situation on the Sino-Soviet split. ${ }^{35}$ Four days later, Mao Zedong again received Snow and discussed with him the presidential debates between Kennedy and Nixon. Mao explicitly told Snow that China would not attack two offshore islands as Jinmen (Quemoy) and Mazu (Matsu) and it "wanted to resolve (the Taiwan issue) through negotiations". He also said that China would not fight the Americans on its own initiatives. ${ }^{36}$

After J. F. Kennedy was elected, Chinese Ambassador to Poland Wang Bingnan indicated to his American counterpart in the Warsaw talks that China hoped the Kennedy Administration "would make some progress in developing Sino-American relations." His statement, of course, had been approved by the Chinese leadership. ${ }^{37}$ Soon, Chinese Foreign Minister Chen Yi conveyed the same message while visiting Burma. ${ }^{38}$

The above mentioned discussion demonstrated that during the first half of 1960, Chinese leaders seriously desired to stabilize Sino-Soviet relations, improve relations with neighboring countries, and create a "new situation in diplomacy," through active promotion of a pragmatic and moderate foreign policy. An important question needs to be further explored: what were the reasons that caused Chinese leaders, including Mao, to reach a consensus in order to promote a pragmatic foreign policy?

An analysis of the disclosed historical materials reveals that Chinese leaders had considered a revision of foreign policy from two aspects. One is the consideration of domestic economic and political programs. They wanted a peaceful international environment so that China could deal with the problems that had emerged and finally accomplish the Great Leap Forward.

32 Jianguo yilai Mao Zedong wengao, Vol. 9, pp. 3-6.

33 Zhou Enlai nianpu, Vol. 2, pp. 321-323.

34 Edgar Snow, The Other Side of the River: Red China Today. New York: Random House, 1962, p. 91.

35 Ibid., pp. 159-61.

36 Mao Zedong, Tong Si Nuo tan Taiwan wenti ji qita, October 22, 1960, Mao Zedong waijiao wenxua, Beijing: Zhongyang wenxian, shijie zhishi chubanshe, 1994, pp. 448-454.

37 Wang Bingnan, Zhongmei huitan jiunian huigu, Beijing: shijie zhishi chubanshe, 1985, p. 83.

38 People's Daily, April 3 and 6, 1961. 
Although by summer of 1959 signs had emerged that the Great Leap Forward was doomed to fail, Chinese leaders, including Mao, did not recognize the severity of its consequences. People, especially top leaders were buoyant, even blinded, by the dazzling "victory" of the Great Leap Forward, which was only built on the coxcombical reports of economic performance across the nation. ${ }^{39}$ At the meeting of the Standing Committee of the Politburo (the SCP) in January 1960, Mao Zedong declared that "the domestic situation is good" and, confident about the prospects of the Great Leap Forward, he suggested that China should strive for peaceful development for about "10, 15 years." ${ }^{40}$

Second, however, Mao came to a very serious assessment about the tendency in international relations. In the meeting of the SCP in Hangzhou in December 1959, Mao claimed that, "the international anti-China tide is rising." ${ }^{41}$ Several months later, Mao again raised the "so-called great anti-China tide." In a comment made on a telegram concerning Chinese exhibition in Pakistan, Mao reminded that we had to understand "the nature and meaning of the so-called great anti-China issue," and "be thoroughly psychologically prepared." ${ }^{2}$ In order to fight the anti-China tide, "the centrality of every issue comes down to the fact that we are doing well in our own unity as well as in our own job." Mao claimed that, "if they give us 40 years, there will have been a great change in international situation by then." ${ }^{43}$ Therefore, Mao and other Chinese leaders did not wish to rule out any disturbance from outside, which became quite severe at the time.

In general, the direction in Chinese foreign policy in this period was by and large determined by the development of domestic situation in China and, to be more specific, by Chinese leaders' considerations of the goals of the Great Leap Forward, and the success or failure of the movement as well as by its consequences.

\section{Shift to the left again in 1962}

The revision of foreign policy since early 1960 was effective, but the pressure on foreign policy, brought by the serious economic recession, first of all by the severe recession in agriculture, was unexpected for the Chinese leaders, especially for Mao. One of the consequences was that foreign policy came under even more pressure.

First of all, Chinese foreign trade was troubled by the fact that neither the production plan for agriculture nor light industry was fulfilled. The Chinese had to request for a postponement in paying back the 1960 loans to the Soviet Union and some East European countries, reduce the scale of imports and exports with

39 Fang Rongkang's reminiscence, to some extent, reflects how people were blinded by an unfounded optimism. Fang Rongkang, "Shelun chuanqilai de lishi” (The History Connected with Editorials), Bainianchao, Vol. 8, 2002, pp. 38-39.

40 WU Lengxi, Shinian lunzhan, Vol. 1, pp. 243, 271.

41 Ibid., p. 235.

42 Mao Zedong, “Guanyu fanhua wenti”, March 22, 1960, in Jianguo yilai Mao Zedong wengao, Vol. 9, p. 95.

43 Ibid., p. 94. Wu Lengxi, Shinian lunzhan, Vol. 1, pp. 234-35. 
them, and receive economic aid from the Soviet Union. ${ }^{44}$ So, China had to stabilize rather than exacerbate the Sino-Soviet relations, thus it had to make compromises.

In addition, two years of continuous poor harvest forced the Chinese government to import food from non-Soviet bloc countries. Meanwhile, a tendency was seen in the development of trade relations in other areas with the Western countries. In August 1960, China proposed "Three Principles for Trade" to gradually resume the Sino-Japanese trade, which had been interrupted in 1958. A civil trade agreement was signed in November and the trade between China and Japan was gradually resumed in $1961 .{ }^{45}$ Chinese leaders were even considering signing an agreement to import food from the United States. ${ }^{46}$ The economic situations had become grim by the end of 1961 . Heavy industry production also plummeted. The unexpected economic recessions further underlined the limited extent of the changes in the Chinese foreign policy during 1960.

Meanwhile, changes in the external environment also brought up the pressure on the need for further revisions in Chinese foreign policy. First, although there was a lessening of tensions in the Sino-Soviet relationship, it was still very fragile. In the first half of 1961, Chinese trade, technological cooperation, and military cooperation with the Soviet Union were resumed and they were further developing. China signed a new trade agreement with the Soviet Union in April 1961. Although the stipulated trade amount was lower than during the previous year, which was mostly an outcome of the Chinese economic recession, the trade relationship between the two states was nonetheless resumed. ${ }^{47}$ Two sides tried to coordinate with each other in international affairs and brief each other on concerning situations. Some high-level visits between the two were being arranged. ${ }^{48}$ Both China and the Soviet Union gave a positive appraisal of this situation.

However, Chinese leaders might have not come to understand that it was impossible for the Sino-Soviet relationship to further develop when ideological disputes were continuing, while it might continue to improve if all ideological disputes were ceased or evaded. Problem was that Mao Zedong believed that the Sino-Soviet solidarity could only be achieved through struggle and clarifying who was right or wrong in theory. To achieve such a victory, Mao argued that the CCP leaders should also understand what real Marxism was, and what revisionism was. ${ }^{49}$ Actually China's restraint in its ideological dispute with the Soviet Union was only reflected in not directly naming the Soviet Communist Party (i.e., the three articles commemorating the 100 year anniversary of the birth of Lenin in the spring of 1960) or indirect criticism (i.e., the dealing with the assessment on the $20^{\text {th }}$ Soviet Communist Party Congress in the Moscow Declaration in 1960), etc.

China and the Soviet Union entered into disagreement over how to deal with the Soviet policy toward Albania in the spring of 1961. Even Chinese leaders

44 Liu Xiao, Chushi sulian banian, Beijing: zhonggong dangshi chubanshe, 1986, p. 105; Zhou Enlai nianpu, Vol. 2. p. 394.

45 Zhou Enlai, "Guanyu cujin zhongri guanxi de zhengzhi sanyuanze he maoyi sanyuanze”, August 27, 1960, in Zhou Enlai waijiao wenxuan, Beijing: Zhongyang wenxian chubanshe, 1990, pp. 289291.

46 Zhou Enlai nianpu, Vol. 2, p. 385.

47 Zhou Enlai nianpu, Vol. 2, p. 385.

48 Li Sheng, Xinjiang duisu (e) maoyishi, 1600-1990, Xinjiang: Xinjiang renmin chubanshe, 1994, p. 635.

49 WU Lengxi, Shinian lunzhan, Vol. 1, pp. 241-243. 
believed that the attacks on Albania by the Soviet leaders were actually aimed to denounce China. ${ }^{50}$ More severely, about sixty thousand Chinese residents in Yili region, Xinjiang crossed the border and fled into the territory of the Soviet Union in the spring and summer of 1962. Regardless of the causes for this incident, one of the unavoidable consequences was the tension across the Sino-Soviet border.

Another important factor was how to deal with the intensifying situation in Vietnam. China's primary strategic goal was to prevent a large-scale American military intervention and to maintain regional stability and support revolutionary movements in the region. Chinese foreign policy would be constrained by this strategic goal. Nevertheless, in terms of Chinese policy of supporting the armed struggle of South Vietnam, China gradually assumed more and more responsibilities with regards to aid and assistance. It is significant to note that Chinese leaders once planned to build an alliance system with neighboring Asian socialist countries, including Mongolia, North Korea, and North Vietnam. For this purpose, Mao Zedong suggested that the proposed agreement could include an article about Chinese military aid. ${ }^{51}$ Under such considerations, it was reasonable for China to provide support and aid when North Vietnam requested it.

Although there was an impulse for assisting the Vietnamese unification war on the part of Chinese leaders, the scale and nature of such assistance was greatly influenced by the intensifying USE military intervention in Indochina. The American intensification of military intervention made Chinese leaders aware that the security of the southern border of China was under more and more severe threat. In early 1962, Chinese government publicly stated that the American military operations in South Vietnam constituted a threat to Chinese security, believing that the American intervention was "directly targeted against the Democratic Republic of Vietnam, and indirectly targeted against China." ${ }^{2}$ The Chinese leaders believed that only through increasing military assistance to North Vietnam, the American military intervention could be defeated. ${ }^{53}$ In May 1962, the Kennedy Administration announced that U.S. ground troops and air force would enter and be stationed in Thailand. Seeing U.S. troops enter into one of China's neighboring country, the Chinese government immediately responded with a tough reaction, publicly calling to "evict American aggressors out of Southeast Asia." ${ }^{54}$ Shortly afterwards, China decided to offer North Vietnam free of charge military equipment that could be used to equip 230 infantry battalions. It may be argued that the American intervention in the region made China's increase of aid to Vietnam an irreversible tendency, and the deeper the U.S. intervened, the more China would aid North Vietnam.

Another factor was the further intensification of the Sino-Indian border conflicts. The Sino-Indian border saw temporary peace after Zhou Enlai's visit to

\footnotetext{
50 "Mao Zedong huijian yindunixiyagongchandang zongshuji yaidi tongzhi de tanhua", January 1, 1961, The Central Archives (hereafter CA).

51 Mao Zedong, "Dui dijie zhongmeng hezuo youhao tiaoyue wenti de piyu,", March 21, 1960, in Jianguo yilai Mao Zedong wengao, Vol. 9, p. 88.

52 "Waijiaobu guanyu meiguo dui yuenan nanfang jiajin wuzhuangganshe de shengmin", February 24, 1962, in Zhonghua renmin gongheguo duiwai guanxi wenjianji (1962), Vol. 9, p. 263.

53 Han Nianlong, ed., Dangdai zhongguo waijiao, Beijing: Chinese Social Sciences Press, 1987, p. 159.

54 Editorial, “Ba meiguo qinluezhe cong dongnanya ganchuqu!”, May 19, 1962, People's Daily.
} 
India in April 1960. Since April 1961, however, the Indian government launched a so-called forward policy. As a response to Indian encroachment, China denounced India's action. Chinese media claimed that the Indian purpose for provoking the border dispute was to concert with the "anti-China tide" raised by the U.S. People's Daily even publicly criticized the top leaders of the Indian Communist Party for not taking the correct stance over the Sino-Indian border issue. ${ }^{55}$

The People's Liberation Army (the PLA) resumed patrols along the border and strengthened its military deployment in the border regions in early 1962. Meanwhile, the Chinese government officially warned the Indian government in its diplomatic note that if the Indian troops refused to retreat from their positions and continued with military provocation, "Chinese frontier defense troops would have no choice but to be forced to defend themselves." ${ }^{56}$ Chinese decision-makers, however, still tried to avoid military conflicts. Chinese leaders were contemplating almost all possible methods to avoid military conflicts, which is evident in the February 1 directive issued by the Central Military Commission and the decree of the "Principle Concerning the Concrete Methods of Resuming Border Patrol and Handling of the Frontier Defense Posts" issued by the PLA General Staff on May $6 .{ }^{57}$

In the summer of 1959, Indian troops provoked a military conflict on the border and inflicted deaths and injuries on the PLA, arousing outrage among the Chinese troops. Mao Zedong's proposal in September 1959 that both the Indian and Chinese troops retreat 20 kilometers so as to disengage the troops of both sides, followed by the unilateral retreat of Chinese troops, to some extent, had taken into consideration the feeling of outrage among PLA troops. Chinese leaders believed that military conflicts would be difficult to avoid if troops of both sides were not quarantined. ${ }^{58}$ As long as India would not give up its demand on Chinese territory and try to resort to force, Chinese military, especially the border troops, would certainly demand a military counterstrike. In another words, Chinese decision-makers had to face the pressure from within that was demanding military response.

Besides tensions along the Chinese borders with the Soviet Union, Indochina, and India, meanwhile, tensions were also mounting on the southeast coast of China. The Jiang Jieshi regime on Taiwan attempted to take advantage of the economic recession on the mainland and launch military attacks. Because the Kuomingtang (the KMT) regime was allied with the U.S., Jiang Jieshi's military preparations put great pressures on the Southeast coast of mainland China. The PLA began combat mobilization, concentrated troops in respective regions, and started conscription earlier than scheduled in May, so as to defeat the probable "combat landing of two to three hundred thousand forces" of Jiang Jieshi troops. ${ }^{59}$ War preparations on the Southeast coast, along with the anti-encroachment

55 Editorial, "Nihelu cedong de yindu fanhua yundong de zhenxiang”, December 7, 1961, People's Daily.

56 Zhonghua renmin gongheguo duiwai guanxi ji, Vol. 9, p. 38.

57 Zhongyin bianjie ziwei fanji zuozhan shi bianxiezu, ed., Zhongyin bianjie ziwei fanji zuozhan shi, Beijing: Military Science Press, 1994, p. 122.

58 Lei Yingfu and Chen Xianyi, Tongshuaibu canmou de zhuihuai, pp. 218-19.

59 "Zhonggong zhongyang guanyu zhunbei fensui jiangfeibang jinfan dongnan yanhai diqu de zhishi", June 10, 1962, in Jianguo yilai zhongyao wenxian xuanbian, Vol. 15, pp. 481-484. 
combat along the Sino-Indian border, had elevated the morale of the PLA to a new height, thus at that time Chinese military had already completed the preparations for combat. ${ }^{60}$

The pressure caused by the economic recession and the stern situation in Chinese foreign relations, finally caused the emergence of a current within the leadership demanding for a comprehensive and systematic critical review of the Chinese foreign policy. The Central Committee of the CCP convened an enlarged working meeting in January 1962 that is the so called Seven-Thousand-Cadre Conference, which aimed at conducting a review of economic policies of the past a few years. However, this directly led to the questioning and open criticism of the Great Leap Forward. ${ }^{61}$ It is worth noting that the policy revision since the Seven-Thousand-Cadre Conference was meant to solve the problems of economic recession, but the scale of policy adjustments was not just constrained to the economic arena. Rather it touched upon some sensitive political issues, such as the democratic system within the party, policy with regards to cadres, policy with regards to intellectuals, and the cultural and educational policy. The implementation of new policies in these areas, indeed, clearly improved the political atmosphere in the whole society. In such atmosphere, it is not surprising that the recognition and criticism of previous mistakes became more profound and sharper, of which Wang Jiaxiang's proposals on foreign policy were part. At that time, Wang was the minister of the Liaison Department of the CPC. Some officials who had previously suffered attacks in party struggles because of raising different opinions, like highranking officials Marshal Peng Dehuai and others, would surely like to appeal.

Indeed, the Seven-Thousand-Cadre Conference did not discuss foreign policy issues directly, nevertheless the report made by Liu Shaoqi on behalf of the Central Committee actually set the tone on foreign policy issues. In the written report, Liu suggested as usual that the CCP, after gaining power, should "aid revolutionary movements of the people of all states in the world, until the realization of a communist world." 62 However, in the ensuing supplementary talk, Liu Shaoqi clearly stated at the beginning that, "to fulfill our international obligations, first of all we have to do well our work at home... the bulk of our attention should be put on the domestic issues." ${ }^{63}$ Liu's words indicated that at the time the Chinese leadership, including Mao Zedong himself, had come to an agreement that "the bulk of attention" should be focused on solving domestic economic problems.

Shortly after the talk by Liu Shaoqi, on February 27 Wang Jiaxiang wrote a letter to Zhou Enlai, Deng Xiaoping, and Chen Yi, in which Wang exposed his opinion and proposals on Chinese foreign policy, and he also wrote few reports afterwards, raising questions concerning Chinese foreign policy. On one hand, Wang Jiaxiang attempted a full-scale, deep, and systematic review of some deeper issues in the

60 Jianguo yilai Mao Zedong wengao, Vol. 10, p. 156.

61 Zhang Tianrong, "1961 nian zhaokai de qiqianren dahui”, in Zhongguo renmin jiefangjun guofang daxue dangshi dangjian zhenggong jiaoyanshi, ed., Zhonggong dangshi jiaoxue cankao ziliao, Vol. 24, pp. 20-21.

62 Liu Shaoqi, "Zai kuodade zhongyang gongzuo huiyi shang de jianghua”, January 27, 1962, in Jianguo yilai zhongyao wenxian xuanbian, Vol. 15, p. 61.

63 Liu Shaoqi, "Zai kuodade zhongyang gongzuo huiyi shang de jianghua”, January 27, 1962, p. 86. 
previous foreign policy, including the fundamental goal of the Chinese foreign policy, a basic judgment about the probability of a world war, an understanding of the relationship between war, peace and revolution, and an understanding of the plausibility of peaceful co-existence, etc. Other suggestions were about further adjustments in foreign policy. ${ }^{64}$

Questions Wang Jiaxiang raised had to some extent challenged a certain "foreign policy route", which was probably the main reason why Mao Zedong later sharply criticized the view of Wang Jiaxiang. To Mao, a concrete policy may be discussed, but the fundamental theoretical thought at the deeper level should never be questioned. However, in hindsight, it is evident that the policies Chinese leaders adopted before the summer of 1962 were in accordance with some proposals for a new foreign policy tactic laid out by Wang Jiaxiang. ${ }^{65}$

Both the speech by Liu Shaoqi and the proposals of Wang Jiaxiang originated from common domestic and international backgrounds. They shared the same principle, which was to argue for a more pragmatic and stable foreign policy, creating a favorable international environment for solving China's economic difficulties. It is out of the question that the deteriorating international situation influenced the complete implementation of those policies and forced the Chinese leaders to adopt some decisive methods, including the use of force, to deal with surrounding pressures.

As explained above, peripheral circumstances of China were deteriorating at the time, while some tendencies were unfavorable for the revision of Chinese foreign policy along the line of pragmatism and stability. In addition, some of the proposals for certain concrete issues put forward in Wang Jiaxiang's reports, though logically speaking, were reasonable, but proved to be impractical under dramatic changes in the domestic and international situation. Nevertheless, in terms of the extent to which the peripheral circumstances of China were deteriorating, they were still not severe enough to compel the Chinese leadership to fundamentally change the foreign policy which was firstly implemented in early 1960 and further explicitly advocated and developed by Wang Jiaxiang in early 1962.

If incidents of various kinds that happened during this period had any impact on Chinese foreign policy, it was mainly to forge a political atmosphere in China which made the radical argument for change of the relatively pragmatic foreign policy more acceptable and popular among the masses. Of course, the deteriorating international environment might have also influenced the psychological state of Mao Zedong. In sum, the main reasons that caused Mao Zedong to criticize the so-called "three kindnesses and one fewness" (san he yi shao) at the Tenth Plenary Session of the Eighth Central Committee which led to the change of Chinese foreign policy, need to be sought among the important

64 On the content of the letter by Wang Jiaxiang, see Li Chen ed., Zhonghua renmin gongheguo shilu, Vol. 2, Jilin renmin, 1994, pp. 656-657; Zhang Tuosheng, "Nanneng de tansuo, kegui de nuli: shilun Wang Jiangxiang dui dang de guoji zhanlue sixiang de gongxian" in Huanqiu tongci liangre: yidai linxiu men de zhanlue sixiang, Beijing: zhongyang wenxian, 1993, pp. 170-183; On other reports by Wang Jiangxiang such as "Shishi qiushi, liangli erxing" and "Luetan dui mouxie guoji wenti de kanfa”, etc., see Wang Jiaxiang xuanji, Beijing: Remin chubanshe, 1989.

65 On Wang Jiaxiang's suggestions concerning concrete issues, see Zhonghua renmin gongheguo shilu, Vol. 2, Beijing: Shijie zhishi chubanshe, 1998, pp. 247-248. 
events in the domestic politics of China. That was the political struggle within the CCP concerning the assessment of the results of the Great Leap Forward.

The Great Leap Forward had its origins in the economy, but then it made an impact on a range of areas. Now the Great Leap Forward waned due to economic difficulties and it also must have had impact on other issues too. Just as the Great Leap Forward elicited a sharp struggle within the party, in fact the denunciation of the Great Leap Forward caused a similar effect. There were different opinions at the so-called Seven-Thousand-Cadre Conference, while those different opinions included those that were both pro and against the Great Leap Forward. The key to the issue was how to treat those differences within the party, especially how Mao Zedong viewed those opinions that denounced the Great Leap Forward.

Mao Zedong's attitudes were manifested in his talks at the Seven-ThousandCadre Conference. On one hand, he set "to carry forward democracy" as the tone of his talk, while on the other hand, he reminded participants of the meeting about the severity of class struggle, and about the "fundamental stance issue" which side one was to take. In particular, in response to the current international environment, Mao pointed out that di xiu fan (imperialists, revisionists, and the anti-revolutionary elements), Jiang Jieshi, together with di fu fan huai you (the landlords, the rich peasants, the bad and anti-revolutionary elements, and the rightists) were all slandering China. ${ }^{66}$ This reminder in a sense demarcated an implicit bottom line for the criticism of the Great Leap Forward. Unless we understand that no criticism was allowed to cross the bottom line, only then can we comprehend the nature of the counterstrike launched by Mao after August 1962. It is evident that Mao believed that the criticism of the Great Leap Forward within the party had already crossed the line and it must be totally rectified.

Following the Seven-Thousand-Cadre Conference, at the Enlarged Meeting of the Standing Committee of the CCP Politburo in February (also called the West Pavilion Meeting) and at the Working Meeting of the Central Committee in May, the mainstream opinion within the Chinese leadership was that a serious degree of the economic recession must be acknowledged and a strategic decision for change of economic policies and a large scale adjustment of the national economy must be made. ${ }^{67}$ However, the situation changed dramatically during the summer. The Central Committee of the CCP convened a working meeting in Beidaihe on August 6,1962 , aimed at preparing for further discussions on the economy. In his talks, however, Mao Zedong revised the scheduled agenda, suggesting that the class struggle issue during the socialist period must be discussed, and he vehemently attacked those opinions that denounced the Great Leap Forward. At the Tenth Plenary Session of the Eighth Central Committee of the Communist Party of China, Mao Zedong further developed his arguments, summarizing the denial of the Great Leap Forward as san feng (Three Winds), namely "hei'an feng" (the dark wind), "dan gan feng"(the work-alone wind), and "fan'an feng" (the reverse-theverdict wind), and alleged the so-called rightist leaders like Liu Shaoqi as "Chinese

66 Mao Zedong, "zai kuoda de zhongyang gongzuo huiyi shang de jianghua”, January 30, 1962, in Zhonggong dangshi jiaoxue cankao ziliao, Vol. 24, pp. 5, 9-10.

67 Jin Congji, Zhou Enlai zhuan, 1949-1976, Vol. 2, p. 683; Xie Chuntao, Dayuejing kuangchao, Zhenzhou, Henan: Henan remin chubanshe, 1990, pp. 236-237. 
revisionists". ${ }^{68}$ The severest consequence was the publication of the bulletin of the meeting that included Mao's famous statement concerning the class struggle issue during the socialist period. ${ }^{69}$

There were two crucial arguments in Mao's criticism of the so-called "Three Winds." The first argument was that the criticism of the Great Leap Forward and its consequences within the party was a reflection of class struggle within the party, and this was "Chinese revisionism", The second one was that "there was a connection between the revisionism at home and abroad", that is, they were colluding. ${ }^{70}$ Such reasoning determined that, when considering foreign policy, during this period Mao could easily link differences in opinion with the so-called "revisionism", especially at a theoretical level.

It was at these two meetings that Mao criticized the views of Wang Jiaxiang. Up to date, however, there is no sufficient information that Mao himself read the letters and reports of Wang Jiaxiang. There are obscure places in the description and introduction of some of his work. For example, whether Mao demonstrated dissatisfaction with the current foreign policy? If he did, was Mao merely dissatisfied with some aspects of the foreign policy, or was he completely dissatisfied with the foreign policy as a whole? What were the concrete factors that led to Mao's criticism of the views of Wang Jiaxiang? etc. ${ }^{71}$

It was a diplomatic event that led Mao Zedong to criticize Wang Jiaxiang's work. In July 1962, at the so-called International Conference on Disarmament and World Peace, the Chinese delegation signed a joint document without such sentences as "against American imperialism," that was drafted by the organizer of the conference. Mao Zedong believed that the essence of this policy was "to leave the leftist, to strengthen the rightist and to sway the middle grounders." At the preparatory meeting of the Tenth Plenary Session of the Eighth CCP Congress, Wang Jiaxiang had to take the responsibility and openly criticize himself. After that, the Foreign Affairs Office of the State Council personally criticized Wang Jiaxiang.

Historical documents that have been disclosed so far showed that what caused Mao to link the suggestions by Wang Jiaxiang with the so-called "three winds" in domestic policy was the remark by the Foreign Minister Chen Yi at the Southeast China Group meeting on September 14. Chen Yi commented that there was a puff of wind that could be called "sanmian he yimian shao" (three-side kindness and one-side fewness). This comment was probably the earliest version of the later phrase of "three kindnesses and one fewness." Chen Yi argued that it was inevitable to struggle with the U.S., the Soviet Union, and India, "political

68 “60 niandai de zhongguo guonei jushi de bianhua yu zhongmei guanxi”, pp. 2267-70; Zhou Enlai zhuan, Vol. 2, pp. 990-994.

69 "Zhongguo gongchandang dibajie zhongyang weiyuanhui dishici quanti huiyi de gongbao", September 27, 1962, in Zhonggong dangshi jiaoxue cankao ziliao, Vol. 24, p. 166.

70 Jianguo yilai Mao Zedong wengao, Vol. 10, p. 199.

71 On the descriptions and remarks on this incident, see Zhu Zhongli, "Suowei de 'san he yi shao,; 'san xiang yi xmie' wenti de zhenxiang”, in Dang de wenxian, No. 5, 1993; Mao Zedong yu Mosike de enenyuanyuan, p. 474; "Nanneng de tansuo, kegui de nuli," p. 181; “Biandong zhong de zuoji guanxi yu zhongguo duimwi zhengce”, p. 191; "60 niandai zhongguo guonei jushi de bianhua yu zhongmei guanxi", pp. 274-276. 
costs-and-benefits calculation" needed to be done, and more support needed to be given to the national liberation movements. It was evident that Mao Zedong liked Chen Yi's remarks a lot and Mao commented on the briefing that it was "worth reading, very good". ${ }^{72}$ Afterwards the "three kindnesses and one fewness", like the domestic "three winds", began to be listed as an subject for criticism.

Chen Yi might not have understood the ultimate purpose of Mao criticizing the "three winds" in domestic policies and the possible consequences it might bring. The key, however, was the phrase of "a puff of wind". This phrase might have been dropped by the speaker unintentionally, but picked up by the listeners carefully. Mao Zedong's praise of the opposition to the so-called "three kindnesses and one fewness" in diplomacy was linked with the opposition to the "three winds" on the domestic front, which was to Mao an issue concerning the guiding thought. That is, what purpose should foreign policy serve? The direct result was that the Tenth Plenary Session of the Eighth Central Committee in fact changed the guiding thought on foreign policy since 1960. Of course, it took time for changes in the guiding thought to be implemented into actual foreign policy, as was the case with the final implementation of the class struggle theory of Mao Zedong. Indeed, the implementation of the changes of the guiding thought of Chinese foreign policy went hand in hand with that of the class struggle theory.

In conclusion, the change of the Chinese foreign policy that took place from 1959 to 1962 was neither caused by the severe-enough-changes in the external environment (i.e., the world war, large-scale invasion by foreign enemies, or other matters threatening the fundamental national interests), nor was it an outcome of a complete re-examination of various aspects of foreign policy (i.e., the situations prior to the Eighth Party Congress and around end 1950s). Rather, it was initiated by the changes in domestic politics and began as changes in the guiding thought of Chinese foreign policy. Also, due to this reason these two issues are worth pointing out in the studies of its impact on the Chinese foreign policy afterwards. Firstly, changes in the guiding thought were gradually implemented into policy making, which, logically speaking, was closely linked with the changes in the domestic political situation. Domestic politics were still playing a major a role. Secondly, changes in the guiding thought might have manifested themselves differently in various aspects of foreign relations, while in certain policy areas these changes in the guiding thought might not even have been carried out. Therefore, a careful and thorough examination of the evolution of Chinese foreign policy after 1962 is necessary. 


\section{Резиме}

Др Ниу Ђун

\section{„Заокрет налево“ кинеске спољне политике од касних 50-их до 1962.}

Кључне речи: кинеска дипломатија, радикализација, гранични сукоб

Од касних 50-их до 1962. кинеска спољна политика је пролазила кроз нагле преокрете и временом започела процес радикализације. Многе студије заступају мишљење да је основна покретачка снага радикализације кинеске спољне политике током овог периода била погоршана ситуација, како у окружењу тако и у односима две суперсиле. Овај рад заснован је на новим историјским доказима и истраживању непрекидних интеракција међународне заједнице и кинеске унутрашње политике у овом периоду. Аутор заговара став да иницијатива за радикализацију кинеске спољне политике проистиче из ситуације у кинеској унутрашњој политици, а нарочито из борбе која се водила унутар вођства Кинеске комунистичке партије око резултата Великог скока напред. 